\title{
Jedenáct let aplikace Nařízení o dokazování ve světle judikatury Soudního dvora Evropské unie*
}

\section{Eleven Years of Application of the Evidence Regulation in the Light of the Case Law of the Court of Justice of the European Union}

\author{
Lucie Zavadilová**
}

\begin{abstract}
Abstrakt
Nařzeni Rady (ES) č. 1206/2001 ze dne 28. kvétna 2001 o spolupráci soudù členských států prì dokazováni v občanských nebo obchodnich vécech je použitelné od 1. ledna 2004. Ve vątazich mezi členskými státy Evropské unie s výjimkou Dánska se tak aplikuje již vice než 11 let. Nař́zení zavádi dva zpưsoby preshraničního dokazování. A to dokazováni dožádaným soudem na základě právni pomoci ve styku s cizinou, a dále primé dokazováni dožadujicim soudem v jiném členském státè. Nicméně, nař̃zeni nedefinuje radu pojmu dilležitich pro vymezeni jeho puisobnosti. Aplikačni praxe však ukazuje, že tato skutečnost nezpuisobuje v členských státech zásadni problémy. Absence definic je prekonávána autonomním víkladem a v posledních letech také judikaturou Soudního dvora Evropské unie. Cílem prìspèvku je analýza tohoto nařżeni, a to zejména v kontextu relevantni judikatury SDEU. Zvláštni pozornost je vènována prínosim, ale $i$ nedostatkim nařzení.
\end{abstract}

Klíčová slova

Nařzeni o dokazování preshranični dokazování; Soudni dvuir Evropské unie; véci občanské a obchodní.

\section{Abstract}

Council Regulation (EC) No 1206/2001 of 28 May 2001 on cooperation between the courts of the Member States in the taking of evidence in civil or commercial matters is applicable as from 1 January 2004. In relationships between the EU Member States (except for Denmark) it has been applied for more than 11 years. The Evidence Regulation provides for two methods of the cross-border taking of evidence - the evidence taking by the requested court and the direct taking of evidence by the requesting court in the territory of another Member State. Nevertheless, the Regulation does not define several concepts which are essential for the determination of its scope of application. However, legal practice shows that this does not cause problems. The absence of express definitions can be overcome with the autonomous interpretation and case law of the Court of Justice of the European Union. The aim of this paper is to analyse the Evidence

* Příspěvek byl zpracován na podkladě autorčiny diplomové práce. Viz ZAVADILOVÁ, Lucie. Právní pomoc ve styku s ciz̨inou ve vécech občanskéch a obchodních. Brno, 2015. 89 s. Diplomová práce. Masarykova univerzita. Právnická fakulta. Vedoucí práce Tereza Kyselovská.

* Mgr. Lucie Zavadilová, doktorandka, Katedra mezinárodního a evropského práva, Právnická fakulta Masarykovy univerzity, Brno / Ph.D. student, Department of International and European Law, Masaryk University, Brno, Czech Republic / E-mail: 378615@mail.muni.cz 
Regulation, especially in the context of the relevant case law of the CJEU. Special attention will also be paid to the advantages and disadvantages of the Regulation.

\section{Keywords}

Civil and Commercial Matters; Court of Justice of the European Union; Cross-border Taking of Evidence; Evidence Regulation.

\section{1 Úvod}

S rozvíjejícími se společenskými a ekonomickými podmínkami se lze v právní praxi stále častěji setkat se soukromoprávními poměry s mezinárodním prvkem. Vzrůstající potřeba provádět nejrůznější procesní úkony v cizině si vynucuje součinnost jednotlivých států. ${ }^{1}$ Mezi nejčastější procesní úkony, jež se realizují cestou právní pomoci ve styku s cizinou, se řadí dokazování. Situace, kdy se v občanském soudním řízení s mezinárodním prvkem vyskytne potřeba získat důkaz v cizině, totiž není v praxi výjimečná. Úsilí států směřující k vytvoření takových právních instrumentů, které přeshraniční dokazování co nejvíce zefektivní, zjednoduší a urychlí, vyvrcholilo na unijní úrovni přijetím Nařízení Rady (ES) č. 1206/2001 ze dne 28. května 2001 o spolupráci soudů členských států při dokazování v občanských nebo obchodních věcech² (dále jen „Nařízení o dokazování“ či „,nařízení‘).

Nařízení bylo přijato na základě čl. 61 a 65 Smlouvy o založení Evropského společenství a je aplikovatelné ve vztazích mezi všemi členskými státy Evropské unie s výjimkou Dánska. ${ }^{4} \mathrm{~V}$ platnost vstoupilo dne 1 . července 2001, nicméně většina jeho ustanovení je použitelná od 1. ledna $2004 .{ }^{5} \mathrm{~V}$ České republice je nařízení přímo použitelné od jejího př́stupu k EU, tj. od 1. května $2004 .^{6}$

Tento př́spěvek se bude uvedeným právním instrumentem zabývat z pohledu 11 let jeho aplikace. Cílem prŕíspěvku je analýza ustanovení Nařízení o dokazování v kontextu judikatury Soudního dvora Evropské unie (dále jen „SDEU“). Za tímto účelem bude

1 STEINER, Vilém. Mezinárodni právni pomoc ve vécech občanskoprávních. 1. vyd. Praha: Nakladatelství Československé akademie věd, 1964, s. 19, 20, 39, 40.

2 ROZEHNALOVÁ, Naděžda a Vladimír TÝČ. Evropský justični prostor (v civilních otázkách). 2. vyd. Brno: Masarykova univerzita, 2006, s. 365. ISBN 80-210-4053-X.

3 Smlouva o založení Evropského společenství, konsolidované znění. In: EUR-Lex [právní informační systém]. Úřad pro publikace Evropské unie [cit. 19. 2. 2015]. Dostupné z: http://eur-lex.europa.eu/ Dále jen „SES.“

4 Bod 3-6, 21, 22 Preambule Nařízení o dokazování. Viz Protokol (č. 22) o postavení Dánska, jak vyplývá ze změn provedených Lisabonskou smlouvou. In: EUR-Lex [právní informační systém]. Úřad pro publikace Evropské unie [cit. 19. 2. 2015]. Dostupné z: http://eur-lex.europa.eu/

5 Čl. 24 Nařízení o dokazování. K legislativní historii vizte např. STORSKRUBB, Eva. Civil Procedure and EU Law: A Policy Area Uncovered. 1. vyd. Oxford: Oxford University Press, 2008, s. 114-118. ISBN 978-0-19-953317-6.

6 SVOBODA, Jiř́i. Dokazování v členských státech EU. AdNotam. 2009, roč. 15, č. 2, s. 49. ISSN 1211-0558. 
nejprve vymezena působnost nař́zení a proveden rozbor jím předvídaných zpơsobů přeshraničního dokazování. ${ }^{7}$ Poté budou vyhodnoceny výhody, ale rovněž i nedostatky tohoto nařizení. Zvláštní pozornost bude věnována relevantní judikatuře SDEU, jež zajišst'uje jednotný výklad jeho ustanovení.

\section{Působnost nařízení}

Nařizení o dokazování se podle čl. 1 odst. 1 „vątahuje na ob̌̌anské nebo obchodní véci, pokud soud clenskébo státu v souladu s právnimi predpisy tohoto státu řádá prǐslušný soud jïnébo členského státu o provedeni dokazování, nebo aby smèl provést dokazováni prìmo v jiném členském státè." Z ustanovení čl. 1 odst. 2 nařízení dále vyplývá, že ,žádost nesmi být podána za účlem dokazování, keteré neni určeno pro zahájené nebo zamýšlené soudni ř̌zeni. "Předpokladem aplikace nařízení je tedy naplnění těchto čtyř podmínek:

- Je zde žádost o provedení důkazu v cizině (dále jen „dožádání‘).

- Dokazování je určeno pro použití v soudním řízení, a to zahájeném nebo zamýšleném.

- Jedná se o věc občanskou či obchodní.

- Dožádání pochází od soudu členského státu. ${ }^{8}$

Nařrizení neposkytuje definici „věcí občanských nebo obchodních.“ Tímto pojmem se SDEU poprvé zabýval v rozsudku ve věci LTU proti Eurocontrol. Z rozhodnutí vyplývá, že pojmy je nutné vykládat autonomně, a to s přihlédnutím primárně k cílům a systematickému uspořádání úmluvy, sekundárně k obecným principům společným právním řádům smluvních států. ${ }^{9} \mathrm{~V}$ kontextu Nařízení o dokazování tak mají být pojmy interpretovány s ohledem na cíl nařízení a Smlouvu o založení Evropského společenství, zejména čl. 65 SES. Obecně se nařízení používá ve věcech vyplývajících z občanského, obchodního, pracovního, spotřebitelského či dokonce soutěžního práva, jde-li o soukromoprávní rúzení. ${ }^{10}$ Nařízení o dokazování se navíc vztahuje i na otázky, jež jsou vyloučeny z působnosti Nařízení Evropského parlamentu a Rady (ES) č. 1215/2012 ze dne 12. prosince 2012 o prríslušnosti a uznávání a výkonu soudních rozhodnutí v občanských a obchodních věcech (dále jen „Nařízení Brusel Ibis“"). Podle ustanovení čl. 1 odst. 2 Nařízení Brusel Ibis se jedná např. o otázky osobního stavu, právní osobnosti a své-

7 V podrobnostech vizte také PAUKNEROVÁ, Monika. Evropské mezinárodní právo soukromé. 2. vyd. Praha: C. H. Beck, 2013, s. 213-216. ISBN 978-80-7400-504-6.

8 Practice guide for the application of the Regulation on the Taking of Evidence. European Commission [online]. European Union, (C) 1995 - 2015 [cit. 28. 2. 2015]. s. 9. Dostupné z: http://ec.europa.eu/justice/ civil/files/guide_taking_of_evidences_en.pdf. Dále jen „Practice guide.“

9 Rozsudek Soudního dvora ze dne 14. ř́ijna 1976. LTU Lufttransportunternehmen GmbH\&Co. KG proti Eurocontrol. Věc C-29/76. Rozsudek se týkal interpretace Úmluvy ze dne 27. záři 1968 o příslušnosti soudů a o výkonu soudních rozhodnutí v občanských a obchodních věcech, ve znění úmluv o prristoupení v rámci postupného rozšiřování Evropské unie (dále jen „Bruselská úmluva“).

10 Practice guide, op. cit., s. 10. 
právnosti fyzických osob, majetkových práv plynoucích z manželských vztahů; otázky závětí a dědění; vyživovací povinnosti; insolvenčních a podobných řízení. Nicméně, z působnosti obou nařízení zůstávají vyloučeny věci daňové, celní a správní ve smyslu čl. 1 odst. 1 Nařízení Brusel Ibis. ${ }^{11}$

Nařízení o dokazování neobsahuje ani definici pojmu „důkaz, “ jehož vymezení je nezbytné k určení rozsahu působnosti nařízení. Výkladu tohoto termínu se věnovala generální advokátka Juliane Kokott ve svém stanovisku ve věci Tedesco. Ze stanoviska vyplývá, že rovněž v tomto prípadě je nezbytné uplatňovat autonomní výklad. Význam a rozsah pojmu „důkaz“ tak má být určen s přihlédnutím ke znění, legislativní historii, systematickému uspořádání a cílům nařízení. ${ }^{12}$ Vzhledem k tomu, že nařízení usiluje o zdokonalení přeshraničního dokazování, je nutné používat nařízením zavedeného zjednodušeného mechanismu v co největší míře. Z uvedeného vyplývá, že pojem „důkaz“ nemá být interpretován př́liš úzce. ${ }^{13}$ Zahrnuje zejména výslechy svědků, znalců a účastníků řízení; předložení veřejných i soukromých listin; místopřísežné prohlášení. ${ }^{14}$

Působnost nařízení se nevztahuje na doručování ${ }^{15}$ ani předběžná nebo zajišt'ovací opatření. ${ }^{16}$ Podle nezávazného prohlášení Rady Evropské unie se nařízení nevztahuje ani na institut pre-trial discovery of documents zahrnující i tzv. fishing expeditions. ${ }^{17}$ Ze stanoviska ve věci Tedesco vyplývá, že toto prohlášení lze vzít při interpretaci nařízení v potaz, slouží-li k vyjasnění v něm obsažených pojmů. ${ }^{18}$ Prohlášení však nelze interpretovat v tom smyslu, že by byly vyloučeny všechny postupy směřující k získání skutkových zjištění před zahájením řízení ve věci samé. Vyloučena nejsou dožádání, jež jsou dostatečně specifikována ve smyslu čl. 4 odst. 1 písm. d) nařízení a jsou spojena s alespoň „zamýšleným“ soudním řízením. ${ }^{19}$ Dokumenty, které jsou požadovány v rámci pre-trial discovery,

11 BETETTO, Nina. Introduction and practical cases on Council Regulation (EC) No 1206/2001 on cooperation between the courts of the Member States in the taking of evidence in civil or commercial matters. The European Legal Forum. Forum Iuris Communis Europae [online]. 2006, vol. 4, s. 138 [cit. 26. 2. 2015]. Dostupné z: http://www.simons-law.com/library/pdf/e/680.pdf

12 Stanovisko generální advokátky Juliane Kokott ze dne 18. července 2007. Alessandro Tedesco proti Tomasoni Fittings Srl a RWO Marine Equipment Ltd. Věc C-175/06, bod 40-42. Dále jen „Stanovisko ve věci Tedesco."

13 Stanovisko ve věci Tedesco, bod 43.

14 Practice guide, op. cit., s. 10.

15 Tuto otázku upravuje Nařízení Evropského parlamentu a Rady (ES) č. 1393/2007 ze dne 13. listopadu 2007 o doručování soudních a mimosoudních písemností ve věcech občanských a obchodních v členských státech a o zrušení nařízení Rady (ES) č. 1348/2000.

16 Problematika předběžných nebo zajišt'ovacích opatření je upravena v čl. 35 Nařízení Brusel Ibis.

17 Council of the European Union. Monthly summary of Council acts, May 2001 [online]. Brussels, 4. 7. 2001 [cit. 27. 2. 2015]. Dostupné z: http://data.consilium.europa.eu/doc/document/ST-10571-2001-INIT/ en/pdf

18 Stanovisko ve věci Tedesco, bod 69.

19 Stanovisko ve věci Tedesco, bod 70 . 
proto musí být konkretizovány. ${ }^{20}$ Nelze tak např̀ žádat o popis dalších nepojmenovaných dokumentů. ${ }^{21}$

Nařízení upravuje pouze předávání dožádání mezi soudy členských států. Přičemž pojem „soud“ nařízení rovněž nespecifikuje. Má se nicméně uplatňovat extenzivní výklad zahrnující všechny orgány členských států, jež mají pravomoc ve věcech spadajících do působnosti tohoto nařízení. ${ }^{22}$ Pokud jde o předávání dožádání, zavádí nařízení mezi soudy členských států přímou formu styku. To znamená, že „soud, u kterébo bylo rízení zahájeno nebo se jeho zahájení zamýšli“"(t). „dožadující soud“) předává dožádání „prímoprǒslušnému soudu jiného členského státu“ („dožádaný soud“). ${ }^{23} \mathrm{Z}$ toho důvodu nařízení vyžaduje, aby každý členský stát určil soudy př́islušné k dokazování. V České republice mohou být dožádanými soudy okresní a krajské soudy, jejichž příslušnost se řídí místem provádění důkazů. Členské státy mají rovněž označit ústřední orgán (central body), který je pověřen zejména předáváním informací soudům a hledáním řešení všech obtíží vznikajících v souvislosti s dožádáním. Pouze ve výjimečných případech se ústřední orgán podîlí na předávání dožádání př́slušnému soudu na žádost dožadujícího soudu. ${ }^{24}$ Státy mají také určit př́slušný úřad (competent authority), jež bude rozhodovat o povolení přímého dokazování podle čl. 17 nařízení. Nicméně, tuto funkci může zastávat i ústřední orgán. ${ }^{25}$ Funkci ústředního orgánu a současně i př́slušného úřadu vykonává v České republice mezinárodní odbor Ministerstva spravedlnosti. ${ }^{26}$

Věcná působnost nařízení zahrnuje dva způsoby dokazování. Prvním je dokazování s využitím právní pomoci ve styku s cizinou. ${ }^{27}$ Takové dokazování provádí př́slušný dožádaný soud na základě dožádání zaslaného mu dožadujícím soudem. ${ }^{28}$ Druhým způsobem je přímé dokazování, jež provádí dožadující soud prrímo v jiném členském státě. ${ }^{29}$

20 Stanovisko ve věci Tedesco, bod 73.

21 Stanovisko ve věci Tedesco, bod 75 .

22 Pojem však nezahrnuje rozhodčí soudy. Viz Practice guide, op. cit., s. 10.

23 Čl. 2 odst. 1 Nařízení o dokazování.

24 Bod 8 Preambule, čl. 2 a 3 Nařízení o dokazování.

25 Čl. 3 odst. 3 Nařizení o dokazování.

26 Pro sdělení členských států podle čl. 22 nařízení vizte webové stránky Evropského soudního atlasu ve věcech občanských, dostupné z: http://ec.europa.eu/justice_home/judicialatlascivil/html/te_otherinfo_cz_cs.htm [cit. 28. 2. 2015]. Jde o informace o př́islušných soudech, ústředních orgánech a příslušných úřadech; a dále také o technických prostředcích pro přijímání dožádání a prrípustných jazycích.

27 NUYTS, Arnaud a Joe SEPULCHRE. Taking of Evidence in the European Union under EC Regulation 1206/2001. Business Law International [online]. 2004, vol. 5, no. 3, s. 326 [cit. 26. 2. 2015]. Dostupné z: http://heinonline.org/

28 Čl. 1 odst. 1 písm. a), čl. 10 - 16 Nařízení o dokazování.

29 Bod 15 Preambule, čl. 1 odst. 1 písm. b), čl. 17 Nařízení o dokazování. 
K urychlení komunikace mezi soudy zavádí nařízení obligatorní používání standardizovaných formulářu. ${ }^{30}$

V rozsudku ve věci Lippens, který se mimo jiné týkal i věcné působnosti nařízení, SDEU zopakoval, že nařízení upravuje pouze uvedené dvě metody dokazování. ${ }^{31}$ Naopak se nevěnuje např. možnosti soudu členského státu předvolat podle svého vnitrostátního práva účastníka původního řízení, jež se nachází na území jiného členského státu, aby se k tomuto soudu dostavil k podání svědecké výpovědi. ${ }^{32}$ Podle SDEU se nařízení aplikuje, rozhodne-li se soud členského státu postupovat jedním z nařízením předvídaných zpơsobů dokazování. V takovém případě musí respektovat nařízením zavedenou proceduru. ${ }^{33}$ Jestliže se však předvolaná osoba dostaví k výslechu dobrovolně, může být za daných okolností postup podle vnitrostátního práva jednodušší, efektivnější a rychlejší než postup podle nařízení. ${ }^{34}$ Skutečnost, že nařízení neupravuje přeshraniční dokazování vyčerpávajícím způsobem, lze také dovodit z čl. 21 odst. 2 nařízení. ${ }^{35} \mathrm{Z}$ uvedeného ustanovení vyplývá, že „narǐzeni nebráni dvèma nebo vice členským státiom zachovávat v platnosti nebo uzavírat dohody nebo ujednáni, které by vice usnadňovaly dokazování, pokud jsou slučitelné s tímto nařżením."

Jak bylo potvrzeno i v rozsudku ve věci ProRail, smyslem nařízení není omezování možností dokazování v jiných členských státech, nýbrž jejich rozšíření a posílení spolupráce soudů členských států při přeshraničním dokazování. ${ }^{36}$ SDEU tímto navázal na svůj dř́ivější rozsudek ve věci Weryński, kde konstatoval, že podle Preambule je cílem nařízení zjednodušení, zefektivnění a urychlení přeshraničního dokazování. Dokazování soudem jednoho členského státu ve druhém členském státě proto nesmí vést k prodlužování vnitrostátního řízení. Nařízením zavedený režim tak ukládá členským státům (kromě Dánska) povinnost odstranit překážky, jež by se v této oblasti mohly vyskytnout. ${ }^{37}$

30 Bod 9 Preambule Nařízení o dokazování.

31 Rozsudek Soudního dvora (prvního senátu) ze dne 6. září 2012. Maurice Robert Josse Marie Ghislain Lippens a další proti Hendrikus Cornelis Kortekaas a další. Věc C-170/11, bod 26. Dále jen „Rozsudek ve věci Lippens.“"

32 Rozsudek ve věci Lippens, bod 27.

33 Rozsudek ve věci Lippens, bod 28.

34 Rozsudek ve věci Lippens, bod 31.

35 Rozsudek ve věci Lippens, bod 33.

36 Rozsudek Soudního dvora (prvního senátu) ze dne 21. února 2013. ProRail BV proti Xpedys NV a další. Věc C-332/11, bod 44. Dále jen „Rozsudek ve věci ProRail.““

37 Rozsudek Soudního dvora (prvního senátu) ze dne 17. února 2011. Artur Weryński proti Mediatel 4 B spółka z o. o. Věc C-283/09, bod 62. Dále jen „Rozsudek ve věci Weryński.““ 


\section{Realizace přeshraničního dokazování}

\subsection{Dokazování dožádaným soudem}

První metodou je dokazování dožádaným soudem na základě dožádání, jež mu zaslal dožadující soud. ${ }^{38}$ Dožádání ani přiložené dokumenty nepodléhají vyššímu ověřování. ${ }^{39}$ Dožádání však musí být přeloženo do úředního jazyka dožádaného státu, př́padně do jednoho z jazyků dožádaným státem akceptovaných. Přiložené dokumenty, jež jsou potřebné k vyřízení dožádání, musí být opatřeny překladem do jazyka dožádání, tj. jazyka formuláře. ${ }^{40}$ Dožádání si mají soudy členských států předávat nejrychlejšími možnými prostředky, které dožádaný stát připouští. Za podmínky zachování obsahu i čitelnosti zasílaných dokumentů lze použít jakékoliv vhodné prostředky. ${ }^{41}$

Dožádaný soud potvrdí dožadujícímu soudu přijetí dožádání do sedmi dnů. Je-li sám nepříslušný, vyrozumí dožadující soud o postoupení dožádání soudu příslušnému. Rovněž jej informuje, je-li dožádání neúplné. V takovém př́ípadě požádá o jeho doplnění. ${ }^{42}$ Dožádaný soud vyřizuje dožádání zásadně podle procesních předpisů dožádaného státu, tj. lex fori. Nicméně, dožadující soud může požádat o výkon dožádání zvláštním postupem podle práva dožadujícího státu. ${ }^{43}$ Dožadující soud může rovněž žádat o provedení dokazování prostřednictvím moderní komunikační technologie (např. videokonference či telekonference). Žádostem dožádaný soud vyhoví, nejsou-li neslučitelné s právním řádem dožádaného státu nebo nebrání-li tomu závažné praktické překážky. Dožádání má být dožádaným soudem vyřízeno nejpozději ve lhůtě 90 dnů od jeho přijetí. ${ }^{44} \mathrm{O}$ případném prodlení a době nutné k vyřízení dožádání musí být dožadující soud vyrozuměn. ${ }^{45}$ Při vyřizování dožádání může dožádaný soud použít přiměřená donucovací opatření podle práva dožádaného státu. ${ }^{46}$

Účastníci ř́zení a př́padně i jejich zástupci mají právo být přítomni (present) při dokazování dožádaným soudem, a dále také právo účastnit se tohoto dokazování aktivně (participate). Předpokladem je, že takové právo vyplývá z právního řádu dožadujícího státu.

38 Čl. 1 odst. 1 písm. a) Nařízení o dokazování.

39 Čl. 4 odst. 2 Nařízení o dokazování.

40 Bod 9 Preambule, čl. 4 odst. 3, čl. 5 Nařízení o dokazování. Česká republika přijímá dožádání vyhotovená $\mathrm{v}$ angličtině, češtině, němčině a slovenštině.

41 Bod 9 Preambule, čl. 6 Nařízení o dokazování. Přípustnými technickými prostředky v České republice jsou pošta, fax a elektronická pošta.

42 Čl. 7 a 8 Nařízení o dokazování.

43 Cílem zvláštního postupu je získat důkazy, jež budou v souladu s právem dožadujícího státu a budou tak plně použitelné v řízení ve věci samé. Viz BETETTTO, op. cit., s. 139.

44 Bod 10 - 12 Preambule, čl. 10 Nařizení o dokazování.

45 Bod 10 Preambule, čl. 15 Nařízení o dokazování.

46 Čl. 13 Nařízení o dokazování. 
Nicméně, i dožádaný soud může tyto osoby požádat podle práva svého státu, aby byly přítomny nebo se účastnily dokazování. ${ }^{47}$ Dokazování dožádaným soudem mohou být př́tomni či se ho aktivně účastnit rovněž představitelé dožadujícího soudu (např. soudní úředníci nebo znalci). Podmínkou je slučitelnost tohoto postupu s právem dožadujícího státu. ${ }^{48} \mathrm{O}$ prrítomnosti či účasti účastníků řízení (jejich zástupců) či představitelů dožadujícího soudu musí být dožádaný soud informován. ${ }^{49}$ Obecně platí, že dožádaný soud není oprávněn zasahovat do práva účastníků řízení (jejich zástupců) či představitelů dožadujícího soudu být přítomni při dokazování. Je však oprávněn stanovit podmínky jejich účasti. ${ }^{50}$

Odmítnout dožádání lze pouze ve výjimečných př́padech. Osoba (např. lékař, kněz či advokát) ${ }^{51}$ se může dovolat práva nebo povinnosti odepřít výpověd', jestliže takové oprávnění nebo zákaz vyplývá z právního řádu dožádaného nebo dožadujícího státu. Pokud jde o právo dožadujícího státu, musí být tato skutečnost uvedena v dožádání či potvrzena dožadujícím soudem. Dožádání bude odmítnuto také v případě, nespadá-li do působnosti nařízení; jestliže k vyřízení dožádání nejsou v dožádaném státě pravomocné orgány moci soudní; či pokud dožadující soud ve stanovené lhưtě nedoplnil neúplné dožádání. Důvodem pro odmítnutí však není výlučná pravomoc dožádaného soudu k řízení ve věci samé, ani skutečnost, že dožádaný stát $\mathrm{v}$ této věci nepřipouštî žalobu. ${ }^{52}$ Skutečnost, že nařízení upravuje důvody pro odmítnutí taxativním způsobem, potvrdil SDEU v rozsudku ve věci Weryński. ${ }^{53}$ Zde konstatoval, že dožádaný soud není oprávněn podmínit provedení výslechu svědka uhrazením zálohy na náhradu nákladů, jež jsou s takovým výslechem spojeny. Nejde totiž o žádný z předpokládaných důvodů pro odmítnutí. ${ }^{54}$

V režimu nařízení obecně platí, že dožádaný soud nemůže za vyřízení dožádání požadovat náhradu nákladů či poplatků. ${ }^{55} \mathrm{~V}$ souladu s autonomní interpretací zahrnují náklady (costs) částky vyplacené soudem třetím osobám v průběhu řízení, zejména svědkům a znalcům. Za poplatky (taxes) se považují finanční prostředky vybrané soudem na jeho činnost. ${ }^{56}$ Dožádaný soud však může od dožadujícího soudu požadovat náhradu nákladů

\footnotetext{
47 Bod 13 Preambule, čl. 11 Nařízení o dokazování.

48 Bod 14 Preambule, čl. 12 Nařízení o dokazování.

49 Čl. 11 odst. 2, čl. 12 odst. 3 Nařízení o dokazování.

50 BETETTO, op. cit., s. 139.

51 BOGDAN, Michael. Concise Introduction to EU Private International Law. 2 ed. Groningen: Europa Law Publishing, 2012, s. 190. ISBN 978-90-89521-088.

52 Bod 11 Preambule, čl. 14 Nařízení o dokazování.

53 Rozsudek ve věci Weryński, bod 53.

54 Rozsudek ve věci Werynski, bod 54.

55 Bod 16 Preambule, čl. 18 odst. 1 Nařízení o dokazování.

56 Rozsudek ve věci Weryński, bod 59.
} 
vynaložených na znalce a tlumočníky, jakož i náhradu poplatků spojených s použitím zvláštního postupu či moderní technologie. Povinnost účastníků řízení k náhradě těchto nákladů či poplatků se řídí právem dožadujícího státu. Dožádaný soud může také požadovat zálohu nebo záruku na předpokládané náklady znaleckého posudku. ${ }^{57} \mathrm{Z}$ rozsudku ve věci Weryński dále vyplývá, že z obecného zákazu požadovat náhradu nákladů a poplatků platí pouze taxativně uvedené výjimky. ${ }^{58}$ Dožádaný soud proto nemůže požadovat např. zálohu na náklady spojené s výslechem znalce ani náhradu nákladů náležejících již vyslechnutým svědkům. ${ }^{59}$ Zmíněné náklady jsou zpravidla nízké, jejich náhrada tudíž nemá prodlužovat řízení a být překážkou mezinárodní spolupráce. ${ }^{60}$

\subsection{Př́mé dokazování}

Druhou v nařízení upravenou metodou dokazování je prrímé dokazování dožadujícím soudem v jiném členském státě. ${ }^{61} \mathrm{O}$ povolení takového dokazování rozhoduje ústřední orgán nebo příslušný úřad dožádaného státu. Ústřední orgán (příslušný úřad) může rovněž stanovit podmínky, za jakých se má dokazování uskutečnit. ${ }^{62}$ Podmínkou může být např. účast soudu dožádaného státu na dokazování, použití jazyka dožádaného státu či zaručení práva svědků na náhradu svědečného. ${ }^{63}$ Přímé dokazování je možné odmítnout z taxativně vymezených důvodů. Lze tak učinit, jestliže dožádání nespadá do působnosti nařízení; neobsahuje veškeré náležitosti; nebo je v rozporu se základními právními zásadami dožádaného státu. ${ }^{64}$

Přímé dokazování lze provést pouze na základě dobrovolnosti, tedy bez použití donucovacích prostředků. Proto i osoby musí být poučeny, že se výslechu podrobují dobrovolně. ${ }^{55}$ Dokazování v dožádaném státě provádí představitel dožadujícího soudu či jiná osoba jako je znalec, diplomatický zástupce, konzulární úředník či komisionár. ${ }^{66}$ Přitom platí, že přímé dokazování se uskutečňuje podle práva dožadujícího státu. ${ }^{67}$

Je nicméně vhodné zopakovat, že nařízení neupravuje přeshraniční dokazování vyčerpávajícím způsobem. Za určitých okolností může být snazší, efektivnější a rychlejší nařídit

\footnotetext{
57 Bod 16 Preambule, čl. 18 odst. 2 a 3 Nařízení o dokazování.

58 Rozsudek ve věci Weryński, bod 63.

59 Rozsudek ve věci Weryński, bod 69.

60 Rozsudek ve věci Weryński, bod 67.

61 Bod 15 Preambule, čl. 1 odst. 1 písm. b), čl. 17 odst. 1 Nařízení o dokazování.

62 Čl. 17 odst. 4 Nařrizení o dokazování.

63 BETETTO, op. cit., s. 141.

64 Čl. 17 odst. 5 Nařízení o dokazování.

65 Čl. 17 odst. 2 Nařízení o dokazování.

66 Practice guide, op. cit., s. 22.

67 Čl. 17 odst. 3 a 4 Nařízení o dokazování.
} 
např. znalecké dokazování bez použití nařízení. ${ }^{68}$ Lze si tak představit dokazování znalcem bez nutnosti získat předchozí souhlas státu, kde se důkaz provádí. ${ }^{69}$ Neexistuje-li však mezi členskými státy žádný právní instrument podle č. 21 odst. 2 nař́zení, a mohlo-li by znalecké „dokazováni za urcítých okolnosti zasáhnout do verejejé moci členského státu, v nëmž k nèmu má dojit, " je postup podle naứzení ,jediným żoisobem, který soudu členskébo státu umo:̌ñ provést żnalecké dokazování prímo v jiném členském státé. "ro

\section{Zhodnocení aplikace nařízení}

Nařízení o dokazování usiluje o sjednocení procesních pravidel přeshraničního dokazování, prosazení „,volného pohybu důkazư “ mezi členskými státy ${ }^{71}$ a o vytvoření evropského civilního procesu. ${ }^{72}$ Jako největší prrínosy nařízení lze uvést zejména tyto skutečnosti:

- Zavádí decentralizovaný systém př́slušných soudů, mezi nimiž se realizuje př́mý styk.

- Zakotvením povinnosti používat standardizované formuláre sjednocuje obsah i formu dožádání, jakož i dalších dokumentů. Přičemž dožádání ani přiložené dokumenty nevyžaduji vyšší ověřování.

- Tzv. jazykem formulářu může být kromě úředního jazyka i jazyk označený dožádaným státem za akceptovaný.

- Nařízení obsahuje striktně vymezené lhůty. Dožádání má být zásadně vyřízeno nejpozději do 90 dnů od přijetí.

- Podporuje se používání moderních komunikačních technologií, jejichž prostřednictvím lze i v mezinárodním kontextu docílit „přímého“ dokazování.

- Limituje důvody pro odmítnutí dožádání, zvláštního postupu i přímého dokazování. ${ }^{73}$

- Za stanovených podmínek nařízení předvídá aktivní účast účastníků řízení, jejich zástupců a představitelů dožadujíćího soudu při dokazování. ${ }^{74}$

Zásadním novem nařízení je zavedení prímého dokazování jako druhé metody provádění důkazů. Jeho výhodou je skutečně „přímé“ dokazování, použivání jazyka dožadujícího soudu a aplikace shodných procesních předpisů na provádění i hodnocení důkazů. ${ }^{75}$ Pří-

\footnotetext{
68 Rozsudek ve věci ProRail, bod 45.

69 Rozsudek ve věci ProRail, bod 49.

70 Rozsudek ve věci ProRail, bod 46 - 48.

71 NUYTS; SEPULCHRE, op. cit., s. 307, 328, 336.

72 BETETTO, op. cit., s. 137.

73 NUYTS; SEPULCHRE, op. cit., s. 321, 323, 326 - 332.

74 BETETTO, op. cit., s. 139, 140.

75 BETETT'TO, op. cit., s. 140.
} 
mé dokazování tak sice představuje podstatný zásah do suverenity státu tím, že na jeho území provádí dokazování cizí soud, avšak děje se tak se souhlasem dožádaného státu. ${ }^{76}$ Praktické problémy jsou spojeny s rozlišováním „dokazování, které je určeno k zamýšlenému dokazování,“ a předběžných nebo zajišt'ovacích opatření ve smyslu čl. 35 Nařízení Brusel Ibis. SDEU se tímto zabýval v rozsudku ve věci St. Paul Dairy. Předběžnými nebo zajišt'ovacími opatřeními jsou podle SDEU taková opatření, jež jsou určena k zachování faktického či právního stavu za účelem ochrany práv, jejichž uznání je požadováno od soudu rozhodujícího ve věci samé. ${ }^{77}$ Naopak, dokazování určené k zamýšlenému dokazování má sloužit ke zjištění, zda je v konkrétní věci vhodné podat žalobu, jaký je základ této žaloby apod. ${ }^{78}$ Takové dokazování vyloučil SDEU z působnosti Nařizení Brusel Ibis a uprednostnil postup podle Nařízení o dokazování. ${ }^{79}$ Nicméně, tento rozsudek je předmětem kritiky. ${ }^{80}$ Zejména z toho důvodu, že postup podle Nařízení o dokazování je zdlouhavější než rozhodnutí o předběžném nebo zajišt'ovacím opatření v režimu Nařízení Brusel Ibis. Podle Heina lze aplikovat Nařízení Brusel Ibis, je-li zde hmotněprávní nárok směřující k vydání uznatelného rozhodnutí. Naopak čistě procesněprávní prostředky k zajištění důkazů řadí do působnosti Nařízení o dokazování. ${ }^{81}$ Lze však konstatovat, že rozdíl mezi oběma instituty a zároveň mezi dvěma nařízeními není definitivně vymezen. A proto lze s napětím očekávat další judikaturu SDEU, která vnese do této problematiky více světla.

Lze shrnout, že přeshraniční dokazování se používáním Nařízení o dokazování obecně zjednodušilo a urychlilo. I když nařízení neobsahuje definice řady pojmů, nezpůsobuje toto $\mathrm{v}$ praxi větší problémy. Tento fakt lze překlenout autonomním výkladem a také postupně se objevující judikaturou SDEU. ${ }^{82}$ Paradoxně největší rezervy při aplikaci nařízení lze spatřovat v nedostatečném využívání prímého dokazování a moderních technologií. Přitom právě tyto nástroje mají potenciál snížit časové i finanční náklady soudního ří-

76 ROZEHNALOVÁ; TÝČ, op. cit., s. 367.

77 Rozsudek Soudního dvora (prvního senátu) ze dne 28. dubna 2005. St. Paul Dairy Industries NV proti Unibel Exser BVBA. Věc C-104/03, bod 13. Dále jen „Rozsudek ve věci St. Paul Dairy.“ Rozhodnutí se týkalo čl. 24 Bruselské úmluvy.

78 Rozsudek ve věci St. Paul Dairy, bod 16.

79 Rozsudek ve věci St. Paul Dairy, bod 25.

80 Viz napr. von HEIN, Jan. Drawing the line between Brussels I and the Evidence Regulation. Note on the opinion of Advocate General Juliane Kokott in Case C-175/06 of 18 July 2007. The European Legal Forum. Forum Iuris Communis Europae [online]. 2008, vol. 1, s. 34 - 36 [cit. 27. 2. 2015]. Dostupné z: http://www.simonslaw.com/library/pdf/e/883.pdf

81 HEIN, op. cit., s. 34, 35.

82 KOMISE ES. Zpráva Komise Radě, Evropskému parlamentu a Evropskému hospodárskému a sociálnímu výboru o uplatñováni nařizeni Rady (ES) c. 1206/2001 ze dne 28. kvétna 2001 o spolupráci soudu členských státu pri dokazování v občanských nebo obchodních vécech [online]. Brusel, 5. 12. 2007, KOM (2007), 769 v konečném znění [cit. 28. 2. 2015]. s. 2 - 6. Dostupné z: http://eur-lex.europa.eu/legalcontent/CS/TXT/ $\mathrm{PDF} /$ ?uri=CELEX:52007DC0769\&from $=\mathrm{CS}$ 
zení s mezinárodním prvkem. Prosazují se rovněž snahy zavést pro komunikaci mezi soudy členských států společný jazyk (nap̌r. angličtinu). Tímto by se řízení ještě více urychlilo, protože by nebylo nutné vyhotovovat překlady dožádání a dalších dokumentů. Ze zjišsění však vyplývá, že uvedené problémy spočívají spíše ve faktickém uplatňování a praxi členských států než v nařízení samotném. I proto se ani př́padná revize nejeví jako nutná. ${ }^{83}$

\section{Závěr}

Nařízení o dokazování neharmonizuje vnitrostátní úpravu dokazování, nýbrž usiluje o posílení spolupráce mezi soudy členských států EU. I přes výše uvedené nedostatky lze nařízení považovat za efektivní nástroj přeshraničního dokazování. Ideou nařízení je zavedení evropského civilního procesu a docílení automatického výkonu dožádání. Vzhledem k tomu, že se v soukromoprávních řízeních stále častěji vyskytuje mezinárodní prvek, roste i význam tohoto nařízení.

Ke zdokonalení přeshraničního dokazování přispěla v posledních letech rovněž judikatura SDEU. Kromě toho, že vymezila řadu důležitých pojmů obsažených v nařízení, vyjasnila také charakter tohoto předpisu. Ten totiž neupravuje přeshraniční dokazování vyčerpávajícím zpơsobem, nýbrž umožňuje postupovat i podle jiných právních instrumentů. Uvedené odpovídá myšlence, že nařízení má spolupráci členských států zdokonalovat, nikoliv být její překážkou.

83 Study on the application of Articles 3 (1)(c) and 3, and Articles 17 and 18 of the Council Regulation (EC) No 1206/2001 of 28 May 2001 on cooperation between the courts of the Member States in the taking of evidence in civil or commercial matters, June 2012. European Commission [online]. European Union, (C) 1995 - 2015 [cit. 6.3. 2015]. s. 138 - 146. Dostupné z: http://ec.europa.eu/justice/civil/files/ final_report_1206_en.pdf 